\title{
THE EUROPEAN GREEN BELT: GENERATING ENVIRONMENTAL GOVERNANCE - RESHAPING BORDER AREAS
}

\author{
JARMO KORTELAINEN \\ University of Eastern Finland, Department of Geographical and Historical Studies, Joensuu, Finland
}

Manuscript received June 30, 2010

Revised version November 9, 2010

Kortelainen J., The European Green Belt: Generating environmental governance - reshaping border areas. Quaestiones Geographicae 29(4), Bogucki Wydawnictwo Naukowe, Poznań 2010, pp. 27-40, 2 figs, 3 tables. DOI 10.2478/v10117-010-0029-y, ISBN 978-83-62662-30-2, ISSN 0137-477X.

AвSTRACT. The article focuses on the European Green Belt (EGB), which refers to efforts to create a network of conservation areas along the borderline that used to divide Europe into the socialist and capitalist blocks. The EGB initiative attempts to link ecologically valuable areas as continuous ecological networks that cross the entire continent. The EGB is divided into three sub-regions: the Fennoscandian and Baltic Green Belt in the North and along the coastline of the Baltic Sea, the Central European Green Belt, and the South-Eastern European Green Belt. The EGB network is studied as a form of environmental governance, and its formation and furtherance are linked with the environmental governance discussion. In addition, the article aims to show that EGB governance is changing the meaning of the former Iron Curtain borders. The borders have been transnationalised since they have become parts of international networks seeking to develop borderless ecological zones. However, the EGB process maintains and reproduces the borders, as the process itself depends on the availability of suitable border areas.

KEY WORDS: environmental governance, border areas, European Green Belt, ecological network, governance-generating network

Jarmo Kortelainen, Department of Geographical and Historical Studies, University of Eastern Finland, PO Box 111, FI80101 Joensuu, Finland; e-mail: jarmo.kortelainen@uef.fi

\section{Introduction}

The European border landscapes have gone through a profound change since the late 1980s. The former Iron Curtain between the socialist and capitalist societies was torn down during the early 1990s when the post-Soviet countries started to open their formerly closed borders. Later, the extension of the European Union towards the east removed most of the barriers to human and material movement which used to characterise those border areas for decades. This has resulted in the growth of various kinds of border-crossing activities ranging from everyday commuting and local-scale cooperation to increased transboundary interaction in trade and politics. All these changes have strongly influenced the way Europe is understood and how the meaning of its internal and external borders has evolved (see Paasi 2001).

The article focuses on the European Green Belt (EGB), a concept which is one of the results of the political and material changes taking place in the European borderlands. The EGB refers to efforts 
to create a network of conservation areas along the borderline that used to divide Europe into the socialist and capitalist blocks. Usually, the concept is used in its regional sense referring to areal zones on the ground. In this article, a broader approach is employed which sees the formation and enhancement of the EGB as an environmental governance process. From this perspective, the EGB means three things. Firstly, it consists of certain land areas with characteristics that make it possible to define them as green belt zones. Secondly, the EGB is simultaneously a tool of environmental governance which aims to bind the areas together and enhance specified ecological and social purposes. Thirdly, the EGB refers to a transnational network of actors which designs conceptions, coordinates the process, and puts the EGB into action. These three interlinked elements together create a whole which is called the European Green Belt (Kortelainen 2010).

The article has a twofold aim. Firstly, it will study the EGB process as a form of environmental governance and link its formation and furtherance with the environmental governance discussion. The empirical case is seen here as a mode of environmental governance which has linked particular border areas as parts of a governance-generating network. A governance-generating network means an assemblage of actors or a system created in order to design and maintain a specific mode of environmental governance (Kortelainen et al. 2010). Secondly, the article aims to show that, as part of this EGB governance generation process, the meaning of the former Iron Curtain borders is changing. EGB activists have consciously tried to improve the extremely negative image of those areas. The borders have also been transnationalised since they have become parts of international networks seeking to develop borderless ecological zones. However, the EGB generation process maintains and reproduces the borders, as the process itself is based on the availability of suitable border areas. Thus, the existence of EGB governance is based on resources provided by border areas.

The article starts with a brief introduction of the environmental governance perspective and the presentation of the concept of a governancegenerating network. It proceeds to describe the formation of the EGB in its three senses as socio- ecological regions on the ground, as a governance tool, and as a network of actors. The concluding section presents ways in which EGB governance utilises and reshapes boundaries and border areas in its governance-generating process. The article is based on literature sources and a systematic analysis of available EGB documents.

\section{The governance-generating network}

The concept of governance is used for different purposes; here I draw on literature which employs it to analyse changes in policy making. It has become a popular notion among scholars studying the changing roles of government and the emergence of new forms of governing (e.g. Rhodes 1996; Jessop 1998; Pierre 2000; Kooiman 2003; Bulkeley 2005). This change has been called a shift from government to governance. The new governance arrangements refer to dispersed, multi-scalar and hybrid stakeholder networks which have challenged hierarchical, territorially bound and organisationally fixed governmental structures as the only forums of policy making. This means, on the one hand, that there has been a "horizontal" transfer of state operations to civil society and business actors, and on the other hand, that there has been a "vertical" shift of responsibilities of the nation-states to other geographical scales.

Echoing Rhodes (1996), governance is often defined as self-organising, inter-organisational networks which complement markets and governmental hierarchies as governing structures. Governance networks allocate resources and exercise control and co-ordination. Some governance scholars exaggerate the importance of nonstate actors in steering public affairs. However, I do not believe that these networks would totally supersede state bodies. Multi-organisational and -sectoral governance networks have complemented existing governmental regulations, formed novel combinations with civil and business organisations, and reorganised governmental hierarchies (see Whitehead 2003).

Sørensen \& Torfing (2005) suggest that such networks have a relatively stable horizontal articulation of interdependent but operationally autonomous actors who interact through nego- 
tiations. They take place within a regulative, normative, cognitive and imaginary framework that, to a certain extent, is self-regulating. Governance networks can emerge and exist in many different forms. Some of them are self-grown and growing from below, and some others are initiated from above. The network relations can be informal in nature or assume the form of highly formalised associations. Usually, they cross organisational boundaries, but they can sometimes be intraorganisational. Their temporal existence varies and the geographical scale can range from local to national and global levels (Sørensen \& Torfing 2005: 205-206).

The development of the governance conception is largely based on studies of public services, international relations and other society-related topics, but in this article the focus is on environmental governance in relation to border areas. The governance concept has also been adopted by numerous researchers dealing with naturalresource-related policies (e.g. Cashore et al. 2004; Bulkeley 2005; McCarthy 2005; Kortelainen et al. 2010). Issues of natural resource use and conservation have generated novel governance arrangements, networks and processes at different spatial scales. Governmental agencies have lost much of their previous monopoly in regulating resource use and protection since various other stakeholders from civil society and business spheres have started to participate in official and unofficial decision making and enforcement. Numerous studies have followed these developments (e.g. van Kersbergen \& van Waarden 2004; Agrawal et al. 2008; Bodin \& Crona 2009). All sorts of publicprivate partnerships are part of everyday practices of environmental planning and management at all geographical scales, from local projects to transnational policies. The following definition summarises the main elements usually associated with environmental governance:

"... environmental governance is synonymous with interventions aiming at changes in environment-related incentives, knowledge, institutions, decision making, and behaviors. More specifically, we use "environmental governance" to refer to the set of regulatory processes, mechanisms and organisations through which political actors influence environmental actions and outcomes. Governance is not the same as government. It in- cludes the actions of the state and, in addition, encompasses actors such as communities, businesses, and NGOs. Key to different forms of environmental governance are the political-economic relationships that institutions embody and how these relationships shape identities, actions, and outcomes..." (Lemos \& Agrawal 2006).

Border-related environmental governance research has usually focused on transboundary environmental governance. This means cooperation activities across national boundaries aiming to manage common environmental problems. While this is an aspect belonging to the EGB initiative, this article sees it more as a transnational network and process. Although one of the major methods of the EGB is to promote cross-border cooperation, its primary idea is to enhance a borderless environmental governance network by linking different green belts and their actors to a common transnational network. Thus, this article is more about transnational environmental governance and how it relates to border areas in this particular case.

I believe that most definitions and studies neglect an important element in environmental governance - the environment itself. It is necessary to include more explicitly socio-ecological milieus which have enabling and conditioning properties and are spatio-temporally contingent. In their discussion of governability, Chuenpagde et al. (2008) include "natural systems" as elementary parts of their holistic approach to environmental governance (see also Jentoft 2007). In another article (Kortelainen et al. 2010) I and my colleagues have developed an approach, a governance-generating network, which incorporates the local socio-ecological milieus as an integral element in environmental governance (Fig. 1).

A governance-generating network is a complex assemblage formed to produce and maintain a distinct type of governance arrangement. It abstracts, combines and modifies information concerning concrete environments and societies, and produces standardised methods which it operationalises and materialises as practices and biophysical outcomes on the ground. On this reading, governance is a relational process in which different elements and agencies are brought into relationships with one another. The networks produce and distribute rules and 


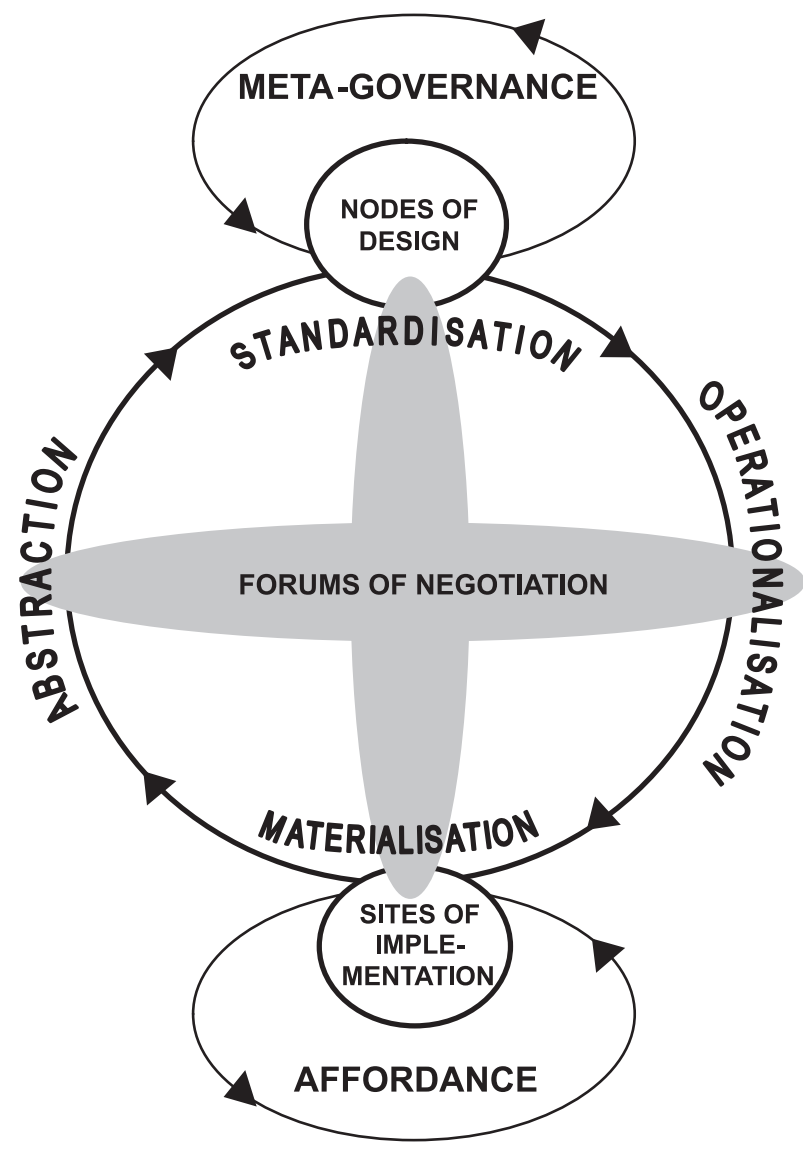

Fig. 1. The governance-generating network.

practices whose intended aim is to affect the way the environments are managed, utilised and conserved. Governance involves heterogeneous sets of actors, including state institutions, nongovernmental organisations, and business enterprises. Governance-generating networks also include socio-ecological sites and circumstances where regulations take place and are enacted and contested.

Although the process of environmental governance is formed as an indivisible actor-network, it is useful, at least for analytical purposes, to divide it into qualitatively different phases. Three ingredients can be distinguished: nodes of design, forums of negotiation, and sites of implementation. Nodes of design are concentrated associations that produce standardised regulations, which are abstract enough to be applicable in and transportable to various socio-ecological locales. Sites of implementation are landscapes on the ground where regulation materialises in a concrete form, and where it is also contested. Forums of negotiation refer to all intermediary situations and associations through which both the design and implementation of regulation must find its way. Both the preparation and enforcement of regulations are typically carried out through several rounds of negotiations in various kinds of hybrid forums which mix different fields and sectors of society (Kortelainen et al. 2010).

The processing of governance depends on the mobility of information and material things. If circulation stops and nothing moves within the network, the governance network fails. In the approach presented here, circulation is divided into four stages: abstraction, standardisation, operationalisation, and materialisation. Abstraction refers to the type of circulation between sites of implementation and nodes of design which transforms concrete physical environments and their socio-ecological properties into generalised knowledge. Standardisation means a process which formulates widely applicable standards. Operationalisation refers to processes through which more general standards are made applicable in various contexts. Materialisation describes negotiations and practices resulting in concrete outcomes in the management of environments (Kortelainen et al. 2010).

Networks of governance do not operate in isolation but overlap, collide with, and are shaped by other networks. The processes of governance are fuelled by information about ecology and society created by scientific and other knowledge producers. The processes receive much of their "energy" from meta-governance and its overarching grand principles and values. Meta-governance has sometimes been called the "governance of governance" (e.g. Jessop 1998; Whitehead 2003). It consists of those institutions and arrangements of governance, such as the Rio process for example, which define the "grand principles" of transnational environmental governance. Meta-governance consists of global expectations, demands and guidelines which enable and steer transnational environmental governance.

Sites of implementation, in turn, possess connections to socio-ecological milieus which affect governance. The concept of affordance can be helpful in this respect. Affordances have been defined as emergent properties attached to environments but which only emerge in relation to certain kinds of necessary interests (Harré 2002; 
Chemero 2003). Although the original usage of "affordance" related to individual perception, it has been used to describe the broader opportunities and constraints environments have to offer. The local and regional combinations of social and ecological features condition, support, transform, allow or deny the materialisation of environmental governance systems and practices. In this approach, environmental governance is afforded by geographically varying socio-ecological milieus, which provide different modes of environmental governance with geographically variable amount of opportunities, support, obstacles, resistance, or building blocks. These relational mixes are coconstructed by a heterogeneous set of relations ranging from locally bound practices to governmental policies and transnational networks. They form locally specific constellations and provide divergent affordances for different environmental governance arrangements (Kortelainen et al. 2010).

The green belt initiative and projects provide us with an illustrating example of the hybrid multi-sited and transnational nature of contemporary environmental governance. The EGB is a governance-generating network which has been designed, promoted and materialised by a heterogeneous set of actors originating from various European countries. The network consists of actors from different societal fields, especially from NGOs, research communities, and governmental agencies. It is designed by central actors forming a node of design, and operationalised through various forums of negotiation. Finally, governance materialises on the ground in sites of implementation, the particular borderlands which have afforded the emergence and evolvement of the EGB initiative and network.

Next I will present the basic features of the EGB. Firstly, I show how it exists as sites of implementation, areas and their socio-ecological milieus on the ground along the external borderlands of the former socialist block. Secondly, I discuss how the EGB has been designed as a governance tool, or a combination of instruments of environmental governance, intended to preserve environments and create connections in these border areas. Thirdly, I will analyse the formation of the EGB network which aims to enhance the concept and implement the EGB initiative on the ground in borderlands. These interlinked and simultaneous elements are in a necessary relation with each other. They are all indispensable and influence each other, forming the environmental governance process called the European Green Belt. Let me start with presenting the EGB areas.

\section{Sites of implementation}

In the governance-generating process, local socio-ecological milieus affect transnational governance in various ways. There is always a "predesign" influence, or all information which circulates in governance networks and makes various stakeholders aware of latent affordances in potential destinations of regulatory operations. This information is present in all planning processes because "designers" and "operationalisers" have to be aware of the affordances of the potential sites of implementation. It is pointless to design governance if the standards are not applicable in their intended destinations. Furthermore, the designed regulatory standards materialise in a co-construction process with each place-specific actors and socio-ecological mix of relations. When geographically specific affordances tangle with governance standards, they create different governance versions in each site, and occasionally local relational mixes do not support, or local resistance blocks, new regulatory attempts (Kortelainen et al. 2010).

The original idea to develop the EGB initiative was strongly shaped by its sites of implementation, i.e. the border areas as a heritage of the cold-war geopolitical order and tension. This cold-war boundary cut Europe from the Barents to the Mediterranean Sea and divided the whole continent into two rather different and separated worlds. A strictly controlled and impenetrable boundary was framed by border zones inaccessible to economic or other human activities. The width of the zones varied, being usually wider on the "socialist" side of the border, and within them the widest in more remote areas. After the collapse of the socialist block, however, it lost its role as a barrier to the movement of people and information. As the significance of the borders diminished, allowing more open communication, the border zones were made thinner or dissolved. 
The heritage of the former geopolitical boundary is still visible in the landscape of various parts of Europe. Closed border zones were usually left out of economic use, making many of the regions ecologically valuable zones or corridors.

This was realised in two separate places. Along the border between Finland and Russia, already in the 1970s, satellite images showed a dark green zone of virgin forests in the borderlands. This started a discussion about a "green belt" on both sides of the border and generated research cooperation (Hokkanen et al. 2007). In turn, German nature conservationists observed many rare species in the closed border zone between East and West Germanys when looking through binoculars (Riecken et al. 2006). In other words, a green belt initiative started to emerge when researchers/ environmentalists dealt with the "undisturbed" borderlands. First it occurred through such media as satellites and binoculars, but later, when the border zones were opened, through field research on the ground. There was a certain affordance for environmental conserva- tion in the borderlands which drew the attention of researchers and environmentalists. This makes it possible to argue that the borderlands, left behind by the former geopolitical tension and confrontation, were among the original "initiators" of the green belt concept. The development of the green belt initiative rested on amateur and scientific observations and was strongly guided by the characteristics of those border areas. Later, the concept and network were extended to other border areas as well.

Before discussing the development and design processes of this particular form of environmental governance, I will shortly present the border areas included in the European Green Belt. This will show the variety of contexts in which the EGB concept has to be operationalised and materialised. As already mentioned, the concept refers to areas along the former boundary between the so-called socialist block and West-European societies. Although it is presented as a continuous zone, in most of the regions it actually consists of scattered protected areas in the vicinity of the

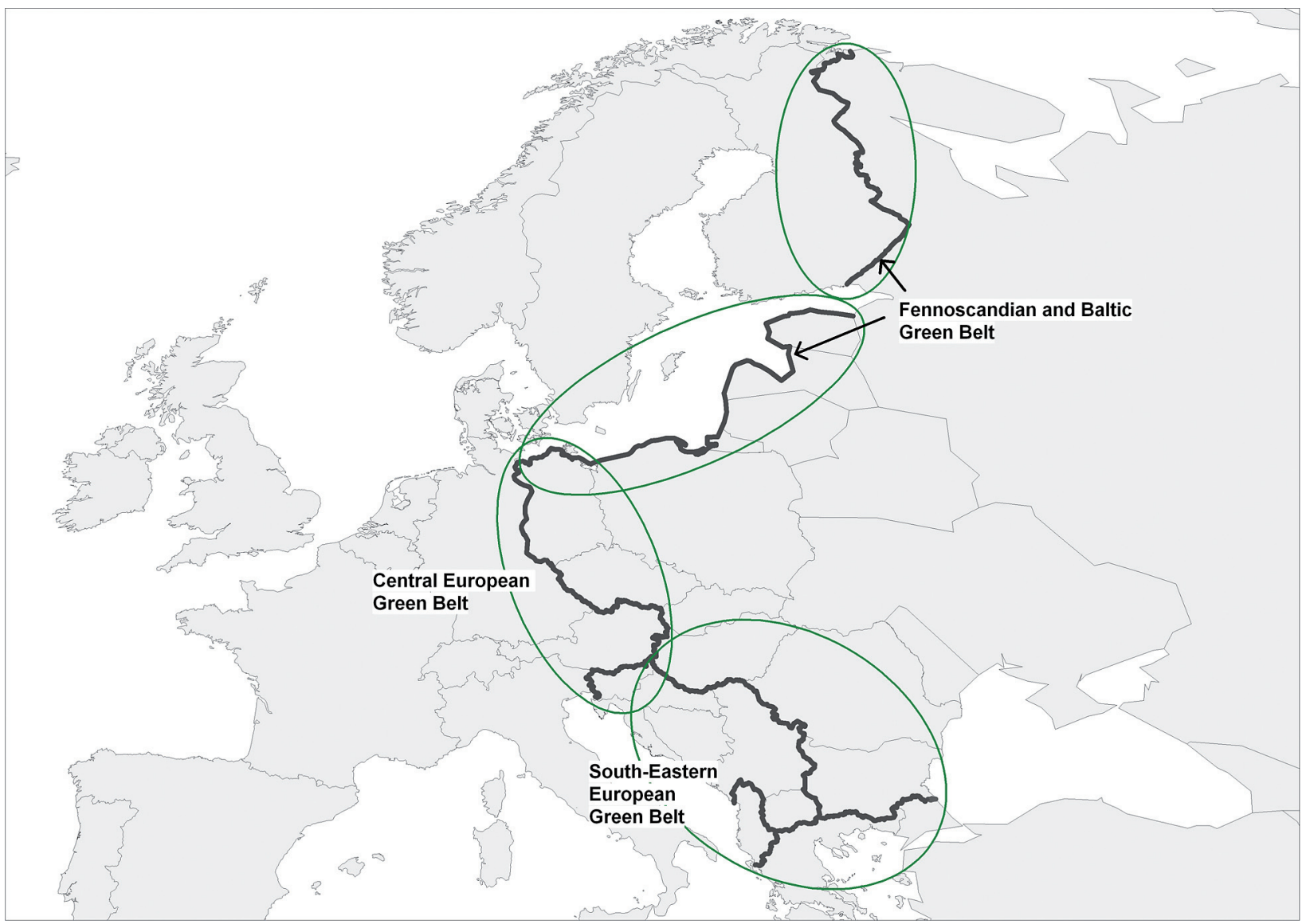

Fig. 2. A map of the European Green Belt. 
border. It is more like a chain than a continuous zone. The activists of the Green Belt network divide the area into three sub-regions: the Fennoscandian and Baltic Green Belt in the north and along the coastline of the Baltic Sea, the Central European Green Belt, and the South-Eastern European Green Belt (see Fig. 2 and Table 1).

The border area between Finland and Russia forms the major part of the Fennoscandian Green Belt. The extreme remoteness and wide border zones, especially on the Soviet side, left huge areas of forests practically untouched (Hokkanen et al. 2007). The origin of the Fennoscandian Green Belt dates back to the time before the collapse of the Soviet Union, since the discussions concerning cross-border cooperation in nature protection started in the late 1980s. As a result, a Friendship Park was established (Karivalo \& Butorin 2006; Lehtinen 2006). The Fennoscandian Green Belt consists of scattered protected areas in Finland, Norway and Russia. In Norway there are four protected areas covering a total of 27,000 hectares of land, in Finland the combined size of the 14 protected areas within the green belt is 580,000 hectares, and in Russia there are 6 protected areas with a total of 508,000 hectares (Karivalo \& Butorin 2006: 40). In addition, there are hundreds of thousands of hectares of old-growth forests under a moratorium along the Russian side of the border conserved by an unofficial agreement between environmental groups and forestry companies (see Kortelainen 2008; Tysiachniouk 2009).

The Baltic Green Belt is the most recent addition to the EGB area. It differs from the other parts of the green belt because it consists predominantly of coastal environments along the east coast of the Baltic Sea. The German section of the BGB consists of a dense net of national nature protection and NATURA 2000 areas. Especially in its eastern part, the coastal strip is unsettled and unused due to the former German Democratic Republic's (GDR) system of restriction and control zones which reached up to 5 kilometres inland (Körner \& Barkowski 2009). In Poland, green belt activities concentrate on projects intended to give agriculture in the coastal zone a more sustainable and less polluting direction (Skorupski 2009).

Lithuania's and Kaliningrad's (Russia) coast is dominated by the 100-kilometre-long peninsula
Table 1. Borders and their length along the European Green Belt.

\begin{tabular}{|c|c|}
\hline Border between countries & Length (km) \\
\hline Norway - Russia & 196 \\
\hline Finland - Russia & 1340 \\
\hline Estonian coastline & 3794 \\
\hline Latvian coastline & 531 \\
\hline Lithuanian coastline & 90 \\
\hline Kaliningrad Oblast coastline & 140 \\
\hline Polish coastline & 491 \\
\hline German coastline & 381 \\
\hline Germany - Germany & 1393 \\
\hline Germany - Czech Republic & 784 \\
\hline Czech Republic - Austria & 362 \\
\hline Austria - Slovakia & 91 \\
\hline Austria - Hungary & 366 \\
\hline Austria - Slovenia & 330 \\
\hline Slovenia - Hungary & 102 \\
\hline Italy - Slovenia & 232 \\
\hline Croatia - Hungary & 329 \\
\hline Hungary - Serbia & 151 \\
\hline Serbia - Romania & 476 \\
\hline Serbia - Bulgaria & 318 \\
\hline Bulgaria - Greece & 494 \\
\hline Bulgaria - Turkey & 240 \\
\hline Macedonia - Greece & 246 \\
\hline Serbia - Albania & 115 \\
\hline Montenegro - Albania & 172 \\
\hline Albania - Greece & 282 \\
\hline
\end{tabular}

Source: http:/ / www.europeangreenbelt.org/002.theborders_sitesdetails.html.

of the Curonian Spit. The peninsula is a protected area consisting of two national parks, one on the Russian and the other on the Lithuanian side (Albrecht 2010). Within the green belt scheme, Lithuanian organisations develop good-practice recommendations for coastal protection and conservation to reduce the threat of erosion and other damage (Morkvenaite \& Blazauskas 2009). In Latvia, public access to the coastal zone was strictly restricted, which left large parts of it untouched. There is now a large national park there as well as a network of NATURA 2000 areas which form the backbone of the green belt on the Latvian shore (Damberga \& Ratkevica 2009). Finally, the Estonian section of the Baltic Green Belt embraces areas of former military bases of the Soviet army. Some of them have been polluted by the army, but many represent areas of ecological importance (Sepp 2009).

In Central Europe, the green belt runs through Germany along the former GDR border. After the 
fall of the Iron Curtain, the border was entirely dismantled; left as its heritage is a narrow zone which had been outside economic and other use for decades. The plan is to protect the narrow central strip which would function as a corridor between larger reservation areas along the zone. The Green Belt continues along the borderline between the Czech Republic and Germany embracing, for example, a transboundary national park (the Bavarian Forest/Sumava). The EGB continues along the Austrian border with the former socialist countries, now the Czech Republic, Slovakia, Hungary and Slovenia, where it reaches the Mediterranean Sea. There are national parks and other important protected areas also in this part of the EGB (Geidezis \& Kreutz 2006).

The South-Eastern European Green Belt consists of areas where the Iron Curtain existed in Southern Europe. Here, the EGB branches off into several lines that criss-cross the Balkans. This part of the EGB separates the former Yugoslavian countries from Hungary, Romania, Bulgaria and Albania, and all those countries from Greece and Turkey. Also the core of the South-Eastern European Green Belt consists of protected areas and other ecologically important sites; in this part of the EGB landscapes are dominated by mountainous environments (Schneider-Jakoby et al. 2006).

The concrete socio-ecological milieus of those border areas affect and afford EGB governance in many ways. Firstly, they "took part" in the initiation of the EGB concept. As relatively intact areas, opened again after the political changes, they induced and enabled interested people to develop the green belt idea to start with (see Riecken et al. 2006). Secondly, the former borders between the East and the West define regions where the green belt concept is possible in the first place since not all border areas are eligible to join the EGB. Due to its definition, it is only restricted to the boundaries of the former socialist countries. Thirdly, the regions influence the EGB concept through their geographical diversity. Geographical variation in socio-ecological circumstances strongly affects the way the concept is defined, interpreted and implemented. Border areas are different in terms of openness, population density, political role, land use, and biophysical characteristics. When materialising the EGB concept on the ground, local and regional socio-ecological milieus have a strong impact on how the projects are carried out. Conservation plans, for example, may cause conflicts with the local population, which require negotiations and new approaches (e.g. Lehtinen 2006).

\section{Standard development}

Transnational environmental governance systems are based on ideas of how to influence environments and their use as well as different stakeholders in a variety of socio-ecological milieus. Therefore, governance has to be standardised, dissociated from any particular place in order to be applicable in as many places as possible. It has to be transmittable and applicable to different localities simultaneously, and adjustable to various settings. Therefore, the nodes seldom generate directly applicable regulatory practices; rather, they produce standards which are "pre-forms" of practical operations. The standards are translated into more tangible criteria and instructions intended to fit regulation to spatially variable socio-ecological contexts. This also makes environmental governance geographically divergent (Kortelainen et al. 2010).

The concept of the EGB itself, its definition and use, is an important standard tool of environmental governance. The concept of the green belt has been used for different purposes. In planning literature, it originates from the 19th-century Garden City movement and has been used in urban planning ever since to describe unbuilt zones around and within urban environments (Thomas 1963; Amati 2008). The concept was extended to environmental planning and management when it started to be used to express the ecological importance of wildlife areas on the former or existing national boundaries. This happened in the late 1980s when it was realised that the former Iron Curtain borderlands represented an important ecological zone and corridor across the European continent.

The green belt concept was used independently in both Finland/Russia and Germany to describe their respective border areas. The environmental cooperation between the Finnish and Soviet authorities started in 1970s, intensified in the 1980s, and especially in the early 1990s when 
the border zones were partly opened for economic activities. A project of a border-forest inventory was carried out in 1992-1994; it showed the ecological value of the ecosystems and species in the area. The results led to an idea of establishing a network of separate protected areas in the Finnish-Russian borderland, and the term "Fennoscandian Green Belt" started to be used to describe it (Lehtinen 2006).

In Germany, the green belt concept developed soon after the fall of the Iron Curtain in 1989. Environmental activists from all over the unified Germany gathered together giving birth to the idea of a green belt. Since the dismantling of the border had revealed the ecological value of the border zone, the environmentalists came up with the idea that the former GDR border should be preserved as a backbone of an ecological network in Central Europe. In 1990, the then environmental minister Klaus Töpfer started to support the idea of the green belt. From 1992 on, the Federal Agency of Nature Conservation started to fund various nature conservation projects along the green belt. The German government declared the German section of the EGB to be part of the national natural heritage in 2005 (Riecken et al. 2006).

Although the initiation and invention of the concept appeared independently at various places, quite soon actors from different regions found each other and started to design a more general concept and framework for the EGB. The initiative includes two standard goals that the actors and projects should try to reach in all parts of the EGB. Firstly, from an ecological perspective, the green belt should be seen as a network which connects parks and protected areas with their surrounding landscapes. Secondly, from a more social perspective, the green belt should foster sustainable development initiatives and bring together people in regions adjoining the former Iron Curtain. The conception of the EGB is based on a vision of ecological networks and on the idea of transboundary cooperation. In other words, the goal is to create connections and mobility, ecologically along the green belt and socially across it. Targets defined in the ecological network perspective especially guided the EGB initiation, but also a major part of activities are concentrated on it, as the following quotation illustrates:
Table 2. Criteria for the determination of elements important for the function of the Green Belt as an ecological network.

\begin{tabular}{|c|c|}
\hline Type & Description \\
\hline Core areas & $\begin{array}{l}\text { Large protected areas like national } \\
\text { parks, including their planned en- } \\
\text { largements, very large SCI/SPAs* or } \\
\text { nature reserves, or UNESCO World } \\
\text { Heritage Sites }\end{array}$ \\
\hline $\begin{array}{l}\text { Cluster of step- } \\
\text { ping stones }\end{array}$ & $\begin{array}{l}\text { a) Small to medium-sized SCI/SPAs } \\
\text { or nature reserves (similar sites with } \\
\text { common conservation targets) which } \\
\quad \text { are grouped together } \\
\text { b) Biosphere reserves (their zonation } \\
\text { usually reflects a similar situation) }\end{array}$ \\
\hline Linear corridors & $\begin{array}{l}\text { Narrow but long continuous pro- } \\
\text { tected areas running on or along the } \\
\text { Green Belt or crossing it (e.g. parts of } \\
\text { the river Elbe, or of the Drava-Mura } \\
\text { river system) and connecting pro- } \\
\text { tected areas along the Green Belt }\end{array}$ \\
\hline $\begin{array}{l}\text { Satellite areas } \\
\text { in buffer zones } \\
\text { or core satellite } \\
\text { area }\end{array}$ & $\begin{array}{l}\text { Small to medium-sized protected } \\
\text { areas in the direct neighbourhood } \\
\text { of/in a buffer zone around core } \\
\text { areas, assumed to be functionally } \\
\text { connected to the core areas or having } \\
\text { a high potential for the development } \\
\text { of connectivity }\end{array}$ \\
\hline Stepping stones & $\begin{array}{c}\text { Small and medium-sized protected } \\
\text { areas (important at a regional or lo- } \\
\text { cal scale, but not at an international } \\
\text { scale) }\end{array}$ \\
\hline
\end{tabular}

*SCI $=$ Sites of Community Importance

SPA $=$ Special Protected Areas

Source: Schlumprecht (2006).

"Based on all the information generated in the different parts of the Green Belt and the history of cooperation across the different borders, it became clear that a similar situation existed throughout the route of the former Iron Curtain. This suggested that this border system could provide the basis or backbone of a European ecological network with large core areas and connecting areas that stretches along the entire length of the continent and that should be preserved and developed further. Therefore the vision was born to establish a Green Belt from the Barents Sea to the Black Sea including the Balkan Green Belt and the border between Italy, Austria and Slovenia, taking into account that the latter section had not been separated by as strong a barrier as other parts." (Riecken et al. 2006: 6).

The ecological perspective of the EGB and its standard criteria are based on a theoretical dis- 
cussion of ecological networks and landscape ecology (e.g. Jongman 1995; Ingegnioli 2002). The ecological network is a concept developed to enhance the conservation of biodiversity. It rests on the idea that usually separate and unconnected nature reserves or other ecologically valuable areas should be connected together by various kinds of ecological corridors or gateways. This is supposed to enable different species to migrate and interact, and thus maintain or even enrich biodiversity. Usually the ecological network is divided into core areas (protected areas or those of high natural value), corridors or stepping stones, and buffer areas (allowing more intensive human use, but taking full account of the provision of ecosystem services). Table 2 is an attempt to create basic criteria of developing the EGB as an ecological network.

The ecological network concept forms the conceptual core of the EGB standard, but the more practical instructions how to enhance the implementation and maintenance of green belts are specified in the Programme of Work document. Experts and national representatives from the countries along the Green Belt prepared these instructions at a meeting in the Fertó-Hanság National Park in Hungary in 2004. It identifies the steps required to implement the green belt concept. The programme of work consists of three elements: 1) direct actions for the establishment of the EGB, 2) the institutional structure and stakeholder participation, and 3) enabling activities (Programme of Work 2005).

The first element lists specific targets and suggests actions that should be carried out. Suggestions include, among others, GIS mapping, research, and data generation of regions. One of the main tasks is also to include the EGB concept in all possible projects, and make it more visible and well known by integrating it into different local and other events. There are also suggestions to activate and increase collaboration and information exchange between different stakeholders involved in, or affected by, the EGB. The second element specifies the roles of actors in the initiative, including transnational NGOs, national NGOs, and governmental bodies. This element details the organisation of the actors and their operational roles (see next section). The third element, enabling activities, identifies operational tools designed to ensure that the two preceding elements are achieved. There are propositions concerning, for example, a web site, workshops, funding opportunities, coordination of separate projects on the ground, and the design of a brand for the EGB (Programme of Work 2005).

The ecological network concept forms the core of the EGB standards. The final target of EGB governance is to create a network that would connect ecologically valuable areas together along the former cold-war boundary. It would form a continuous chain crossing the entire continent. The other goal of the EGB, cross-border contacts, receives much less attention in EGB documents. The social aspects of the EGB seem to be perceived more like an implement for, or a by-product of, the ecological programme.

\section{Building the networks}

There is a vast variety of border regions where the EGB initiative should work. This fact has of course caused difficulties in creating standards that would fit all circumstances in the intended destinations. The operationalisation and materialisation of EGB standards is carried out through national and local operations. "It was clear from the beginning that as this ecological network would travel through an immensely diverse set of countries, the structure and implementation of the Green Belt would differ in the various regions depending on the specific natural, historical, political and social preconditions" (Riecken et al. 2006: 6).

Thus, the EGB network has been designed and built keeping in mind the geographical variation. It is a network of actors that set the process in motion, promote the concept, and try to implement it on the ground in different parts of the Belt. At the beginning, there were actors working separately on a national basis. German ENGOs organised meetings and developed the idea of the EGB. The Finnish and Russian authorities carried out cooperation projects in their own border areas. However, for the idea to become a European project, international networks and collaboration practices had to be created. This was one of the issues discussed at the all-European meeting in Hungary in 2004. As a result of the discussions, 
the Programme of Work set the main guidelines for building the network of actors and specified their roles and goals in generating EGB governance. According to the programme, the EGB network of actors is intended to be open to all countries and stakeholders along the belt.

Today the European Green Belt community represents quite a typical form of environmental governance where actors from different societal fields form a hybrid network. This is indicated by the EGB organisation itself in the following words: "A wide variety of actors is active in the European Green Belt initiative. Members are national and international NGOs, state agencies for nature conservation and regional development, protected areas management authorities and the regional coordinators, and national focal points..." (http://europeangreenbelt.org).

Nodes of design are hubs of networks which include actors taking part in constructing governance methods as widely applicable norms, models, tactics or guidelines aiming to affect environments and their management. Nodes consist of intensive and relatively constant bundles of relations which can concentrate in a particular location or can have a more scattered form. Spatially, nodes can emerge as punctual knots where "designers" work together in physical proximity and on a daily basis. A node of design can also consist of sub-nodes if standards are formed in intensive interaction between them. However, they are always functional nodes which accumulate and compress discursive, political and scientific resources around efforts to produce standardised methods or to exercise coordination (Kortelainen et al. 2010).

In the EGB network a node of design consists of different actors in various locations having a more dispersed spatial form. The main coordinating body of the EGB is the initiative's secretariat. The International Union for Conservation of Nature (IUCN), a transnational ENGO, coordinates the pan-European Green Belt initiative. It links the stakeholders with each other and with the secretariat, contributes to the development of projects, and acts as an information hub. The Green Belt Coordination Office is embedded in the IUCN Programme Office in Belgrade. Regionally, the Green Belt organisation is divided into three organisational sections: Fennoscandia and Baltic, Central Europe, and South-Eastern Europe. Each of the regions has a regional coordinator.

The Programme of Work defines some tasks for the stakeholders involved. Because the operationalisation of the EGB initiative depends strongly on legal, political and cultural characteristics, in each nation the network has a structure based on the national division. Countries bordering the Green Belt should have a representative authorised by the national authorities. These representatives are called National Focal Points, and at the moment there are 18 such focal points. Not all the countries along the Green Belt have Focal Points, among them Norway, Russia and Finland. Focal Points are either members of NGOs, researchers and their research institutes, or administrators of protected areas (http:// www.europeangreenbelt.org). National Focal Points are important actors for national governments since they are the ones whose task it is to promote the Green Belt concept in state conservation policies. Another of their tasks is to intensify collaboration with governmental bodies, also other than conservation bodies (Programme of Work 2005).

Finally, the network of actors also includes the numerous concrete projects that take place in various locations within the Green Belt regions. The aim of those projects is to attract actors to join the EGB and thus to expand the significance of the concept as an environmental governance tool. The actual work of the EGB actors consists of projects at different spatial scales. There are activities called pan-European projects including occasional international workshops and a special database project establishing a common, transboundary database containing information on important protected areas and other related topics. However, most of the projects are regional or local; examples are listed in Table 3 below.

The above projects connect sites of implementation with the transnational EGB network. These are the sites where EGB standards, goals and principles are materialised and made visible. The projects should work in concert with the criteria developed by EGB designers which promote the ecological network concept and cross-border cooperation, among others. In effect, the EGB network, through its projects at the implementation 
Table 3. Some examples of regional and local EGB projects.

\section{Regional projects:}

Interreg III B Project: Protection and valorisation of the longest habitat system in Europe - Green Belt

Balkan Lynx Recovery Programme 2006-2008 (FYR Macedonia, Albania, Kosovo)

Balkan Green Belt as Ecological Corridor for Wolf, Bear and Lynx (Jablanica-Shebenik Mountain Range)

Civil-military Cooperation for Transboundary Nature Conservation along the European Green Belt Interreg IV B, Baltic Sea Region Programme: Baltic Green Belt project Local projects:

Integrating Local Communities and Nature Protection in the European Green Belt (Gornje Podunavlje Special Nature Reserve, Serbia)

Raising Awareness about Biodiversity and Sustainable Community Development in the Stara Planina Area Experience Green Belt (Germany)

Testing and Developing the Project (F+E Vorhaben) "Habitat Type Inventory of the German Green Belt"

Billy Bushcricket walks along the Green Belt (Southern Thuringian Green Belt)

Land Purchase in the German Green Belt

Living Werra - Lebendige Werra

Species and Habitat Protection Project "Steinachtal and Linder Ebene"

Wo ist meine Zeltbahn? Where is my shelter? Green Belt Photo Exhibition Cross Border Stones

The Pamirian Winterfat (ÖNB) Willow Pollards (ÖNB)

Source: http:/ / www.europeangreenbelt.org

sites, starts to transform the borderlands to a certain degree (see Leibenath et al. 2010).

\section{Conclusions}

This article has discussed the EGB as a governance-generating network which links various actors and sites together to design, transfer and implement transnational environmental governance. All the included elements have been necessary for the emergence and growth of the EGB initiative and process. Firstly, through their socioecological properties the borderlands along the boundaries of the former socialist countries have afforded, and made it possible, to initiate and implement such a concept as the EGB. Secondly, the concept itself has been further designed and employed as a standard tool of environmental gov- ernance when it became connected with the theoretical basis of ecological networks and standard measures were prepared to guide efforts in all parts of the EGB. Thirdly, due to the transnational character of the concept, a broad international network of actors has been created reaching from the Barents Sea to the Mediterranean, and from governmental offices in national capitals to local projects in the borderlands.

It has been shown that implementing the EGB is not only a process that takes place through projects on the ground, but also a construction work which tries to attract as many actors as possible to support and join the initiative. An especially strong emphasis seems to have been put on attracting governmental agencies and local groups to support the initiative in all the countries involved and in the border regions. One of the main goals is trying to integrate the EGB concept with governmental projects and policies. The EGB construction work also takes place at a more symbolic level. A branch of the EGB initiative has developed which tries to make the idea and the approach associated with the Green Belt visible and widely known. This includes, for instance, the design of a logo and its use on all possible occasions, as well as publications and events related to the Green Belt.

The EGB is an umbrella notion which covers and integrates projects, protected areas, actors and institutions under a common concept and "label". Most of them would also exist without the broader EGB concept. Hence, it is extremely difficult to assess the significance of green belt governance. Doubts have been presented about the ecological importance of the process since the belt seems to resemble a scattered archipelago rather than a connected ecological network. The pan-European ecological network resembles a conceptual framework rather than a material thing on the ground (see Lehtinen 2006). The EGB significance rests more on its political, social and economic potentials.

The transnational environmental governance network of the EGB is a border projects dependent on certain kinds of border areas and simultaneously changing them. In addition to the ecological aspects and their effects on the ground, the EGB network has - to a certain extent - changed the role and function of boundaries and border areas. 
The former Iron Curtain borders have received a new transnational role as ecological networks and corridors, or loci of transboundary cooperation. In other words, a new transnationalisation of borderlands has emerged based on the crossEuropean network and border-crossing activities. Borders in their traditional and more functional sense, as dividing lines, have lost a great deal of their importance.

The EGB network plays a role in this boundary "disappearance". At the same time, however, it maintains the borders. Although its goal is to develop a borderless ecological network, the whole network depends on borders of a particular kind. That is why it is vital for the EGB to reproduce the borders; their histories and changes or their crossings are repeated innumerable times in EGB documents and their rhetoric. The former Iron Curtain borders are the essential resources and elementary parts of the governance-generating network whose legitimacy is partly based on its ability to change their negative image and enhance better relations across them. Therefore, the borders have to be "kept alive", though in a new sense.

\section{References}

Agrawal A., Chatre A. \& Hardin R., 2008. Changing governance of the world's forests. Science, 320 (5882): 14601462.

Albrecht M., 2010. Transboundary governance of the Curonian Spit World Heritage Site. Journal of Environmental Planning and Management, 53 (6): 725-742.

Аматі M., (ed.), 2008. Urban Green Belts in the twenty first century. Ashgate, Aldershot.

Bodin Ö. \& CRONA B.I., 2009. The role of social networks in natural resource governance: What relational patterns make a difference? Global Environmental Change, 19(3): 366-374.

BulKeley H., 2005. Reconfiguring environmental governance. Towards a politics of scales and networks. Political Geography, 24: 875-902.

Chemero A., 2003. An outline of a theory of affordances. Ecological Psychology, 15: 181-195.

Chuenpagde R., Kooiman J. \& Pullin R.S.V., 2008. Assessing governability in capture fisheries, aquaculture and coastal zones. The Journal of Transdisciplinary Environmental Studies, 7(1): 1-20.

Cashore B., Auld G. \& Newsom D., 2004. Governing through markets: Forest certification and the emergence of non-state authority. Yale University Press, New Haven and London.

Damberga A. \& RAtKevica A., 2009. Military heritage as a chance for sustainable tourism in Latvia. European Green Belt Newsletter, 1/2009.
Geidezis L. \& Kreutz M., 2006. The Central European Green Belt. In: Ullrich K. \& Riecken U. (eds), The Green Belt of Europe - From vision to reality. IUCN, Gland.

Harré R., 2002. Material objects in social worlds. Theory, Culture and Society, 19: 23-33.

Hokkanen T.J., HeikKilä R., MakKonen T., Kashevarov B., NYKÄNEN R. \& IESHKO E., 2007. The emergence of new approaches in East-West relations: combining nature protection and local development along the Green Belt of Fennoscandia. In: Lähteenmäki M. (ed.), The flexible frontier - Change and continuity in Finnish-Russian relations. Aleksanteri Institute, Helsinki.

INGEGNIOLI V., 2002. Landscape Ecology: A widening foundation. Springer, Berlin.

JENTOFT S., 2007. Limits of governability: Institutional implications for fisheries and coastal governance. Marine Policy, 31: 360-370.

JESSOP B., 1998. The rise of governance and the risks of failure: The case of economic development. International Social Science Journal, 50 (1): 29-45.

Jongman R.H.G., 1995. Nature conservation planning in Europe: developing ecological networks. Landscape and Urban Planning, 32 (3): 169-183.

Karivalo L. \& Butorin A., 2006. The Fennoscandain Green Belt. In: Terry A., Ullrich K. \& Riecken U. (eds), The Green Belt of Europe - From vision to reality. IUCN, Gland.

Van Kersbergen K. \& Van WaArden F., 2004. "Governance" as a bridge between disciplines: Cross-disciplinary inspiration regarding shifts in governance and problems of governmentality, accountability and legitimacy. European Journal of Political Research, 43: 143-171.

Koolman J., 2003. Governing as Governance. Sage, London.

KORTELAINEN J., 2008. Performing the green market - creating space: emergence of the green consumer in the Russian woodlands. Environment and Planning A, 40 (6): 12941311.

Kortelainen J., 2010. The European Green Belt as a form of environmental governance. KRIHS Special Report, 15: 63-81.

Kortelainen J. \& Kotilainen J. (eds), 2006. Contested environments and investments in Russian Woodland Communities. Kikimora Publications, Helsinki.

Kortelainen J., Kotilainen J. \& Tysiachniouk M., 2010. Generating environmental governance through transnational networks (Forthcoming article).

KÖRNER E. \& BARKOWSKI J., 2009. Stimulating sustainable coastal politics in Germany. European Green Belt Newsletter, $1 / 2009$.

LeHtinen A.A., 2006. Postcolonialism, multitude, and the politics of nature. On the changing geographies of the European North. University Press of America, Lanham.

Leibenath M., Blum A. \& StutzRIEMER S., 2010. Transboundary cooperation in establishing ecological networks: The case of Germany's external borders. Landscape and Urban Planning, 94 (2): 84-93.

Lemos C.M. \& Agrawal A., 2006. Environmental Governance. Annual Review of Environment and Resources, 31: 297-325.

McCarthy J., 2005. Scale, sovereignty, and strategy in environmental governance. Antipode, 37 (4): 731-753.

Morkveinatte J. \& BlazAusKas N., 2009. Sustainable coastal protection along the lithuanian coast. European Green Belt Newsletter, 1/2009.

PAAsI A., 2001. Europe as a social process and discourse considerations of place, boundaries and identity. European Urban and Regional Studies, 8 (1): 7-28. 
PIERRE J., 2000. Debating governance: authority, steering, and democracy. Oxford University Press, New York.

Programme of Work of the European Green Belt, 2005. IUCN Europe, Brussels.

RHodes R.A.W., 1996. The new governance: governing without government. Political Studies, 44 (4): 652-667.

RieCKEn U., UllRich K. \& Lang A., 2006. A vision for the Green Belt in Europe. In: Ullrich K. \& Riecken U. (eds), The Green Belt of Europe - From vision to reality. IUCN, Gland.

SCHLUMPRECHT H., 2006. Mapping the European Green Belt. In: Terry A., Ullrich K. \& Riecken U. (eds), The Green Belt of Europe - From vision to reality. IUCN, Gland.

Schneider-Jacoby M., Schwaderer G. \& Fremuth W., 2006. The South-Eastern European Green Belt. In: Ullrich K. \& Riecken U. (eds), The Green Belt of Europe - From vision to reality. IUCN, Gland.
Sepp K., 2009. Assessing \& promoting the Green Belt Estonia. European Green Belt Newsletter, 1/2009.

SKORUPSKI J., 2009. Promoting ecological agriculture in Poland. European Green Belt Newsletter, 1/2009.

Sørensen E. \& Torfing J., 2005. Network governance and post-liberal democracy. Theory \& Praxis, 27 (2): 197-237.

THOMAs D., 1963. London's green belt: the evolution of an idea. The Geographical Journal, 129 (1): 14-24.

TYSiACHNIOUK M., 2009. Conflict as a form of governance: The market campaign to save the Karelian forests. In: NystenHaarala S. (ed.): The changing governance of renewable natural resources. Ashgate, Farnham.

WhiteHEAD M., 2003. "In the shadow of hierarchy": metagovernance, policy reform and urban regeneration in the West Midlands. Area, 35 (1): 6-14. 